\title{
Soil Fungal Diversity of the Aguarongo Andean Forest (Ecuador)
}

\author{
Ernesto F. Delgado ${ }^{1}$, Adrián T. Valdez ${ }^{1}$ (D), Sergio A. Covarrubias ${ }^{2}$, Solveig Tosi ${ }^{3, *(D)}$ and Lidia Nicola ${ }^{3, *(\mathbb{D})}$ \\ 1 Laboratories Life Sciences, Research Group, Department of Environmental Engineering, INBIAM, \\ Salesian Polytechnic University, Calle Vieja 12-30 and Elia Liut, Cuenca 010102, Ecuador; \\ mdelgado@ups.edu.ec (E.F.D.); adrian.valdez@utalca.cl (A.T.V.) \\ 2 Academic Unit of Chemical Sciences, Campus Siglo XXI, University of Zacatecas, \\ Carretera Zacatecas-Guadalajara km 6, La Escondida, Zacatecas 98160, Mexico; tiberio_claudio@hotmail.com \\ 3 Mycology Laboratory, Department of Earth and Environmental Sciences, University of Pavia, \\ Via S. Epifanio 14, 27100 Pavia, Italy \\ * Correspondence: solveig.tosi@unipv.it (S.T.); lidia.nicola01@universitadipavia.it (L.N.)
}

Citation: Delgado, E.F.; Valdez, A.T.; Covarrubias, S.A.; Tosi, S.; Nicola, L. Soil Fungal Diversity of the Aguarongo Andean Forest (Ecuador). Biology 2021, 10, 1289. https:// doi.org/10.3390/biology10121289

Academic Editor: Daniel A. Henk

Received: 6 November 2021

Accepted: 1 December 2021

Published: 7 December 2021

Publisher's Note: MDPI stays neutral with regard to jurisdictional claims in published maps and institutional affiliations.

Copyright: (c) 2021 by the authors. Licensee MDPI, Basel, Switzerland. This article is an open access article distributed under the terms and conditions of the Creative Commons Attribution (CC BY) license (https:/ / creativecommons.org/licenses/by/ $4.0 /)$.
Simple Summary: The Kingdom Fungi is one of the richest in species, most of which are still unknown. Many fungal species are hidden in the tropics, the area richest in biodiversity on earth. In this paper, a mycological analysis is presented on a vast number of soil samples collected in the Aguarongo forest, an important Andean Natural Reserve of Ecuador. The study was carried out by analyzing the total DNA extracted from the soil and unveiled a total of more than 400 species of fungi. The most abundant species belong to Ascomycota and Mortierellomycota; some are important beneficial fungi for the environments such as antagonistics of fungal pathogens or nematode predators, while others are well-known producers of nutraceutical and pharmaceutical compounds. Based on the results of this study, a picture of the mycodiversity of Aguarongo forest soil was obtained. This area hides a huge number of unknown fungal species that could be discovered; thus, the protection of the Aguarongo forest is mandatory.

Abstract: Fungi represent an essential component of ecosystems, functioning as decomposers and biotrophs, and they are one of the most diverse groups of Eukarya. In the tropics, many species are unknown. In this work, high-throughput DNA sequencing was used to discover the biodiversity of soil fungi in the Aguarongo forest reserve, one of the richest biodiversity hotspots in Ecuador. The rDNA metabarcoding analysis revealed the presence of seven phyla: Ascomycota, Basidiomycota, Mortierellomycota, Mucoromycota, Glomeromycota, Chytridiomycota, and Monoblepharomycota. A total of 440 identified species were recorded. They mainly belonged to Ascomycota (263) and Basidiomycota (127). In Mortierellomycota, 12 species were recorded, among which Podila verticillata is extremely frequent and represents the dominant species in the entire mycobiota of Aguarongo. The present research provides the first account of the entire soil mycobiota in the Aguarongo forest, where many fungal species exist that have strong application potential in agriculture, bioremediation, chemical, and the food industry. The Aguarongo forest hides a huge number of unknown fungal species that could be assessed, and its protection is of the utmost importance.

Keywords: Andes; environmental DNA; fungal biodiversity; metabarcoding; natural reserve; forest ecosystems tropical mycobiota vulnerable species

\section{Introduction}

The Andes represent the largest mountain range on Earth and cross the western part of South America. In Ecuador, the inter-Andean valley is composed of humid areas at high altitudes, with physiognomies ranging from grasslands to forest formations, combined with andisol soils, which develop from volcanic ash and show little or moderate evolution, forming a unique ecoregion. The forest soils in the Andean highlands have high biodiversity and unique environmental characteristics. It is an endangered ecosystem, 
and little is known about its microbial community. Fungi represent an essential functional component of terrestrial ecosystems as decomposers and biotrophs (mutualists, pathogens, and necrotrophs), and they are one of the most diverse groups of Eukarya [1,2].

The soil fungal communities are affected by numerous biotic and abiotic factors, including seasons, soil characteristics, age and plant host species, and different soil managements [3,4]. The study of the ecological factors that underlie the dynamics of fungal communities remains a challenge due to its high taxonomic and ecological diversity.

Molecular methods based on PCR and ribosomal DNA sequencing have been successfully used to identify fungi at different taxonomic levels in different environmental samples and have helped to elucidate the ecological conditions that affect the structure and diversity of fungal communities [5-7]. The internal transcribed spacer region (ITS) is now widely used as a DNA barcode marker for the identification of fungal species [8]. Recent studies have demonstrated the potential of advances in DNA sequencing for quantifying and characterizing the fungal diversity, especially in those areas of the planet where biodiversity is very rich and complex [9].

Ecuador is one of the 17 megadiverse countries in the world, according to the World Conservation Monitoring Centre (WCMC) of the United Nations Environment Program. Ecuador has approximately 4.6 million hectares that have been declared as natural areas, which contain invaluable biodiversity and are a rich source of necessary ecological services. The fungal biodiversity of the natural areas in Ecuador is little known due to its extreme richness and complexity. The analysis of genetic material directly extracted from environmental samples coupled with DNA next-generation sequencing technology is useful in discovering its mycobiota and the monitoring of its biodiversity over time and in different ecological conditions [10].

Rich literature can be found on the fungal biodiversity of Ecuador, mainly focused on taxonomy and distribution of a single taxon at the species or hierarchical higher level [11-15]. Many papers focus on pathogenic fungi for important crops or on the relation between fungi and environments [16-19]. Recently, environmental fungal DNA was analyzed for community composition studies of disturbed areas [20,21] or specific substrates such as plants [22,23]. Investigation of mycobiota of natural areas in Ecuador focused on biodiversity, distribution, and ecology of mycorrhizae [24-26]. Data collected from environmental DNA concerning the entire mycobiota from natural areas and reserves of Ecuador are missing or rare.

In this work, high-throughput DNA sequencing was used to discover, for the first time, the biodiversity of soil fungi in the Aguarongo forest reserve, one of the richest biodiversity hotspots in the Ecuadorian Andes.

\section{Materials and Methods}

\subsection{Declaration of Ethics}

Specific permits were obtained for the field study described to collect 100 soil samples representative of the protected area. Samples did not include endangered or protected animal or plant species.

\subsection{Sample Collection}

The study site was located in Ecuador, in the Aguarongo forest, declared "protective vegetation area No. 10" by the Ecuadorian Ministry in 1985 (BVPA-El Bosque de Vegetación Protectora Aguarango) (Figure 1). The Aguarongo forest is one of the few fragments of Andean forest remaining in the Andean mountains in the province of Azuay and corresponds to low montane humid forest. The area, with an extension of 2080 ha, is the main water supply for the communities of the Gualaceo, Sigsig, and Cuenca cantons in southern Ecuador, resulting from its 191 streams [27,28]. It is located in the southern part of the middle basin of the Paute River, between $78^{\circ} 48^{\prime} 54^{\prime \prime}$ and $78^{\circ} 52^{\prime} 22^{\prime \prime} \mathrm{W}$, and $2^{\circ} 52^{\prime} 37^{\prime \prime}$ and $2^{\circ} 59^{\prime} 43^{\prime \prime} \mathrm{S}$. The altitude ranges between 2900 and 3320 m.a.s.l., and the average annual rainfall is $820 \mathrm{~mm}$. The area is characterized by a dense closed forest, with $2-8 \mathrm{~m}$ tall tree 
cover, shrubs, and grass layer. The flora is dominated by Weinmannia spp. (sarar), Eugenia spp. (arrayan), Podocarpus spp. (huabisay), Cerdela spp. (Cedar), Alnus acuminata (alder), Myrica pubescens (laurel), and Oreocallis grandiflora (Gañal) [27].

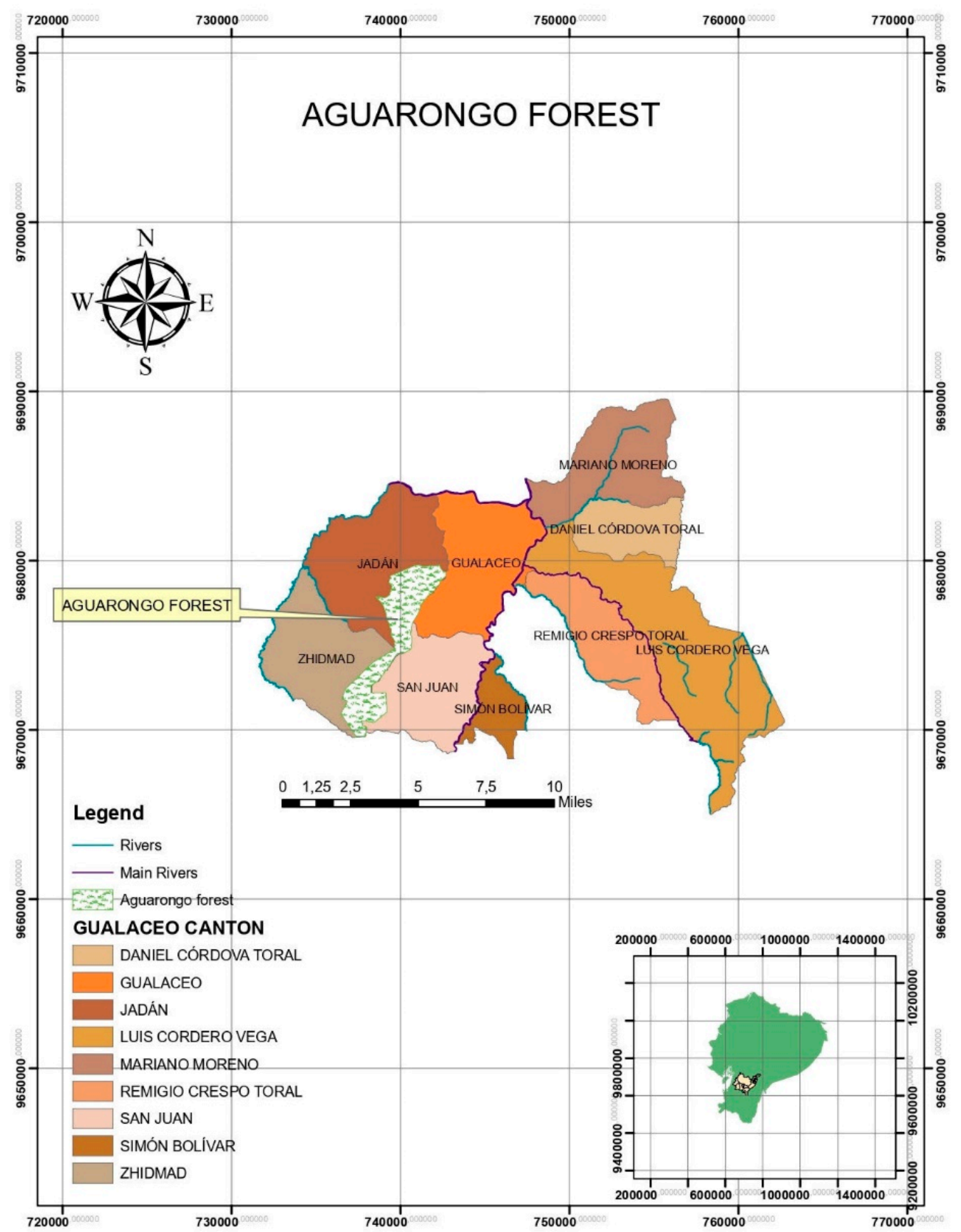

Figure 1. The upper part shows the location of the Aguarongo protective forest within the area that corresponds to the Gualaceo canton and its parishes, province of Azuay, Ecuador. The lower part of the figure shows the map of Ecuador with the location of the province of Azuay.

The Aguarongo forest was divided into three altitudinal levels (L1, L2, L3; Table 1), and in November 2017, 35, 35, and 30 soil samples were taken for each level, making a total of 100 soil samples. Each sampling point was selected by a completely random design in an area of $10 \mathrm{~m}^{2}$. The number of samples per altitudinal level completely covered the extent of the altitudinal level. By means of a manual shovel, soil cores were taken (10 cm length $\times 10 \mathrm{~cm}$ width $\times 20 \mathrm{~cm}$ depth), and the shovel was disinfected with $75 \%$ ethanol after each sampling [29]. The soil samples were then placed in a cooler with dry ice 
for their conservation, transported to the laboratory, and stored at $-20{ }^{\circ} \mathrm{C}$ (for metagenomic analyses) or $4{ }^{\circ} \mathrm{C}$ (for other analyses). Subsequently, animals, stones, and plant debris were removed, and the samples were sieved at $2 \mathrm{~mm}$.

Table 1. Sampling sites and number of soil samples.

\begin{tabular}{cccc}
\hline Sampling Site & Number of Collected Samples & Altitude & Coordinates \\
\hline L1 & 35 & $3101-3146$ & $2.936^{\circ} \mathrm{S} ; 78.8339^{\circ} \mathrm{W}$ \\
L2 & 35 & $3159-3173$ & $2.936^{\circ} \mathrm{S} ; 78.842^{\circ} \mathrm{W}$ \\
L3 & 30 & $3175-3221$ & $2.959^{\circ} \mathrm{S} ; 78.855^{\circ} \mathrm{W}$ \\
\hline
\end{tabular}

\subsection{Soil Physicochemical Analysis}

The soil physicochemical analyses were carried out on soil samples from each sampling site (L1, L2, L3) following the methods reported by Bloem et al. [30]. From each area (L1, L2, L3), three replicates were prepared by pooling $100 \mathrm{~g}$ aliquots derived from each soil sample. Each pooled sample was then sifted ( $2 \mathrm{~mm}$ mesh) and homogenized, based on the method reported by Uroz et al. [29].

Hydrogen potential was measured using an INESA pH meter (Shanghai REX Instrument Factory, Shanghai, China) in a 1:5 suspension of ultrapure water. The organic matter was evaluated following the Walkley-Black method [31]. The elements sodium, iron, zinc, manganese, copper, sulfur, calcium, magnesium, potassium, and phosphorus were measured using inductively coupled plasma-atomic emission spectrophotometry (ICP-AES), exchangeable aluminum and chlorides by ion chromatography, and nitrogen by Kjeldahl volumetric titration. Each measurement was performed in triplicate, and the mean for each sampling site was reported.

\subsection{Environmental DNA Extraction from Soil Samples}

Microbial DNA was extracted from $0.5 \mathrm{~g}$ of soil from each of the 100 samples using the Power Soil DNA isolation kit (MO BIO Laboratories, Carlsbad, CA, USA. U.U.), according to the manufacturer's instructions. DNA extracted from five neighboring soil samples was combined, creating a total of 20 pooled samples (Supplementary Table S1), in order to optimize sequencing and to avoid pseudoreplication of sample points (the extension of the Aguarongo forest is limited). The quality and size of the DNA were verified by electrophoresis in 1\% agarose gel. Additional quality control of the extracted DNA was performed, measuring 260/280 and 260/230 ratios. The DNA concentration was determined using Qubit Fluorometric Quantitation (Life Technologies, Carlsbad, CA, USA).

\subsection{PCR Amplification and Next-Generation Sequencing (NGS, Illumina MiSeq)}

Polymerase chain reaction (PCR) amplification of ITS hypervariable regions (6F-4R) was performed using the extracted DNA as a template for amplifying an internal fragment of the ITS gene. Primers ITS 3 (5'-GCA TCG ATG AAG AAC 132 GCA GC-3'), and ITS 4 (5'-TCC TCC TAT TGA TAT GC- $\left.3^{\prime}\right)$, joined to a multiple identifier sequence (Illumina), were used [32]. For each sample, amplicons were generated in several duplicate PCRs using mixtures $(25 \mu \mathrm{L})$ containing 25 pmol of each primer, 1x KAPA HiFi Hotstart Ready Mix (Kapa Biosystems, Wilmington, MA, USA), and $10 \mathrm{ng}$ of the DNA template. The PCR program was performed following White et al. [32], consisting of an initial denaturation stage at $95^{\circ} \mathrm{C}$ for $3 \mathrm{~min}$, followed by 25 cycles at $95^{\circ} \mathrm{C}$ for $30 \mathrm{~s}, 55^{\circ} \mathrm{C}$ for $30 \mathrm{~s}, 72{ }^{\circ} \mathrm{C}$ for $30 \mathrm{~s}$, and final extension at $72{ }^{\circ} \mathrm{C}$ for $5 \mathrm{~min}$. Amplicons of the same treatment were grouped to reduce PCR variability and purified using Ampure accounts XP (Beckman Coulter, USA), according to the manufacturer's instructions. After PCR cleaning, the Illumina sequencing adapters were joined by a second stage of PCR using the Nextera XT index kit (Illumina Inc., Sand Diego CA, EE U.U.). The mixture contained Nextera Index Primers 1 and $2(5 \mu L)$, 2 KAPA HiFi HotStart ReadyMix $(25 \mu \mathrm{L})$, DNA $(5 \mu \mathrm{L})$, and PCR grade water $(10 \mu \mathrm{L})$ for a total volume of $50 \mu \mathrm{L}$. The PCR program in this step consisted of an initial denaturation step at $95^{\circ} \mathrm{C}$ for $3 \mathrm{~min}$, followed by 8 cycles at $95^{\circ} \mathrm{C}$ for $30 \mathrm{~s}, 55^{\circ} \mathrm{C}$ for $30 \mathrm{~s}, 72{ }^{\circ} \mathrm{C}$ for $30 \mathrm{~s}$, 
and a final step at $72{ }^{\circ} \mathrm{C}$ for $5 \mathrm{~min}$. Amplicons were cleaned as described above. Amplicon libraries were quantified using Qubit (Invitrogen, CA, EE). The samples were combined in equimolar quantities ( $4 \mathrm{nM}$ each) and were sequenced on a MisEq platform (paired-end sequencing $2 \times 300$, considering $2 \times 50,000$ reads/sample) of Illumina in Macrogen (Seoul, South Korea), according to the manufacturer's instructions.

\subsection{Taxonomic Allocation of Sequence Readings and Statistical Analysis}

The paired-end reading sequences generated from Illumina MiSeq were processed using the software package "Quantitative Insights into Microbial Ecology 2" (QIIME 2, v2018.6) [33]. In short, the reads were trimmed, filtered, and merged with the DADA2 complement [34], keeping the sequences with a minimum quality score of 25 , a minimum length of $240 \mathrm{bp}$ for reverse readings, and a maximum length of $260 \mathrm{bp}$ for advanced readings. Merged reads were collapsed into representative sequences or amplicon sequence variants (ASVs), then ASVs were filtered through de novo chimera using VSEARCH [35]. The sequences that were observed only once or twice (singletons and doubletons) were removed. The taxonomy of ASV was assigned at a $99 \%$ sequence identity based on the UNITE v7 database [36]. Nonfungal sequences were removed from the subsequent analysis, and the ASV table was rarefied to a uniform depth (100,000 sequences per sample) to reduce bias related to the depth of sequencing.

Taxonomy and shared files produced in QIIME were imported into R [37] using the Phyloseq package ver. 1.32.0 [38]. Alpha diversity was calculated using the Chao1, Simpson, and Shannon indices. Beta diversity was investigated using nonmetric multidimensional scaling (NMDS) on a Bray-Curtis distance matrix. The statistical test PERMANOVA was used, implemented in the vegan $R$ package, ver. 2.5.6 [39], to assess any statistically significant difference among the fungal communities in the different sampling areas.

\subsection{Access Numbers}

High-performance sequencing datasets were deposited in the NCBI Biosamples data with access numbers SAMN11854455, SAMN11854456 197, and SAMN11854457 for Location 1, Location 2, and Location 3 ITS DNA metabarcoding libraries, respectively.

\section{Results}

\subsection{Soil Chemical Characteristics}

Concentrations of $\mathrm{N}, \mathrm{P}, \mathrm{K}, \mathrm{Mg}, \mathrm{Ca}, \mathrm{S}, \mathrm{Cu}, \mathrm{Mn}, \mathrm{Zn}, \mathrm{Fe}, \mathrm{Na}$, exchangeable $\mathrm{Al}$, and chlorides are presented in Table 2 for each site. The analyses revealed that some chemical parameters vary significantly among the sampling sites; altitudinal levels could be one of the conditions that influence the chemical properties of the soil, but type of soil must be considered as well.

Table 2. Soil chemical properties. Values are expressed in $\mathrm{mg} / \mathrm{kg}$ for each compound, except $\mathrm{Al}$ expressed in meq/100 g, while $\mathrm{N}$ and organic matter are expressed in \% s.m.s. Values with different letters in the same column are significantly different $(p<0.05)$.

\begin{tabular}{ccccccccc}
\hline Sampling Sites & $\mathbf{p H}$ & Organic Matter & $\mathbf{N}$ & $\mathbf{P}$ & $\mathbf{K}$ & $\mathbf{M g}$ & $\mathbf{C a}$ & $\mathbf{S}$ \\
\hline L1 & $4.9^{\mathrm{b}}$ & $10.9^{\mathrm{a}}$ & $0.68^{\mathrm{b}}$ & $3.6^{\mathrm{b}}$ & $203.3^{\mathrm{b}}$ & $425.7^{\mathrm{b}}$ & $1776.3^{\mathrm{b}}$ & $846.4^{\mathrm{b}}$ \\
L2 & $4.8^{\mathrm{a}}$ & $15.5^{\mathrm{a}}$ & $0.82^{\mathrm{a}}$ & $5.9^{\mathrm{a}}$ & $128.0^{\mathrm{a}}$ & $162.7^{\mathrm{a}}$ & $564.7^{\mathrm{a}}$ & $1012.6^{\mathrm{a}}$ \\
L3 & $4.6^{\mathrm{a}}$ & $12.3^{\mathrm{a}}$ & $0.71^{\mathrm{a}}$ & $5.3^{\mathrm{a}}$ & $126.7^{\mathrm{a}}$ & $177.7^{\mathrm{a}}$ & $885.3^{\mathrm{a}}$ & $790.4^{\mathrm{a}}$ \\
\hline Sampling Sites & $\mathbf{C u}$ & $\mathbf{M n}$ & $\mathbf{Z n}$ & $\mathbf{F e}$ & $\mathbf{N a}$ & $\mathbf{C l}$ & $\mathbf{A l}$ & \\
\hline L1 & $10.5^{\mathrm{b}}$ & $118.7^{\mathrm{b}}$ & $16.0^{\mathrm{a}}$ & $834.3^{\mathrm{a}}$ & $28.7^{\mathrm{a}}$ & $11.8^{\mathrm{a}}$ & $6.4^{\mathrm{a}}$ \\
L2 & $8.7^{\mathrm{a}}$ & $72.7^{\mathrm{a}}$ & $15.7^{\mathrm{a}}$ & $926.0^{\mathrm{a}}$ & $31.3^{\mathrm{a}}$ & $15.1^{\mathrm{a}}$ & $6.9^{\mathrm{a}}$ & \\
L3 & $12.7^{\mathrm{a}}$ & $107.7^{\mathrm{a}}$ & $16.0^{\mathrm{a}}$ & $1197.3^{\mathrm{b}}$ & $24.3^{\mathrm{a}}$ & $371.8^{\mathrm{b}}$ & $7.1^{\mathrm{a}}$ \\
\hline
\end{tabular}

The values of $\mathrm{pH}, \mathrm{N}, \mathrm{P}, \mathrm{K}, \mathrm{Mg}, \mathrm{Ca}, \mathrm{S}, \mathrm{Mn}$, and $\mathrm{Cu}$ are similar in $\mathrm{L} 2$ and $\mathrm{L} 3$ but are significantly different from $\mathrm{L} 1$. The content of $\mathrm{Zn}, \mathrm{Na}$, and exchangeable $\mathrm{Al}$ did not show 
differences between L1, L2, and L3. Site L1 showed the greatest differences, with lower values of $\mathrm{N}$ and $\mathrm{P}$ compared to the other locations, while in the case of $\mathrm{Mg}$ and $\mathrm{Ca}$, it presents higher values.

\subsection{Soil Fungal Assemblage Composition}

The sequencing on the Illumina MiSeq Platform of the DNA of the 20 pooled soil samples produced a total of 3,699,594 reads, with an average of $184,979.7$ reads per sample. After the cutting and filtering process, the reads were reduced to 2,794,683, with an average of 139,734 reads per sample. It was observed that L1 showed the highest abundance with an average of 833 OTUs, followed by L2 with an average of 780 OTUs and L3 with an average of 711 OTUs (Figure 2).

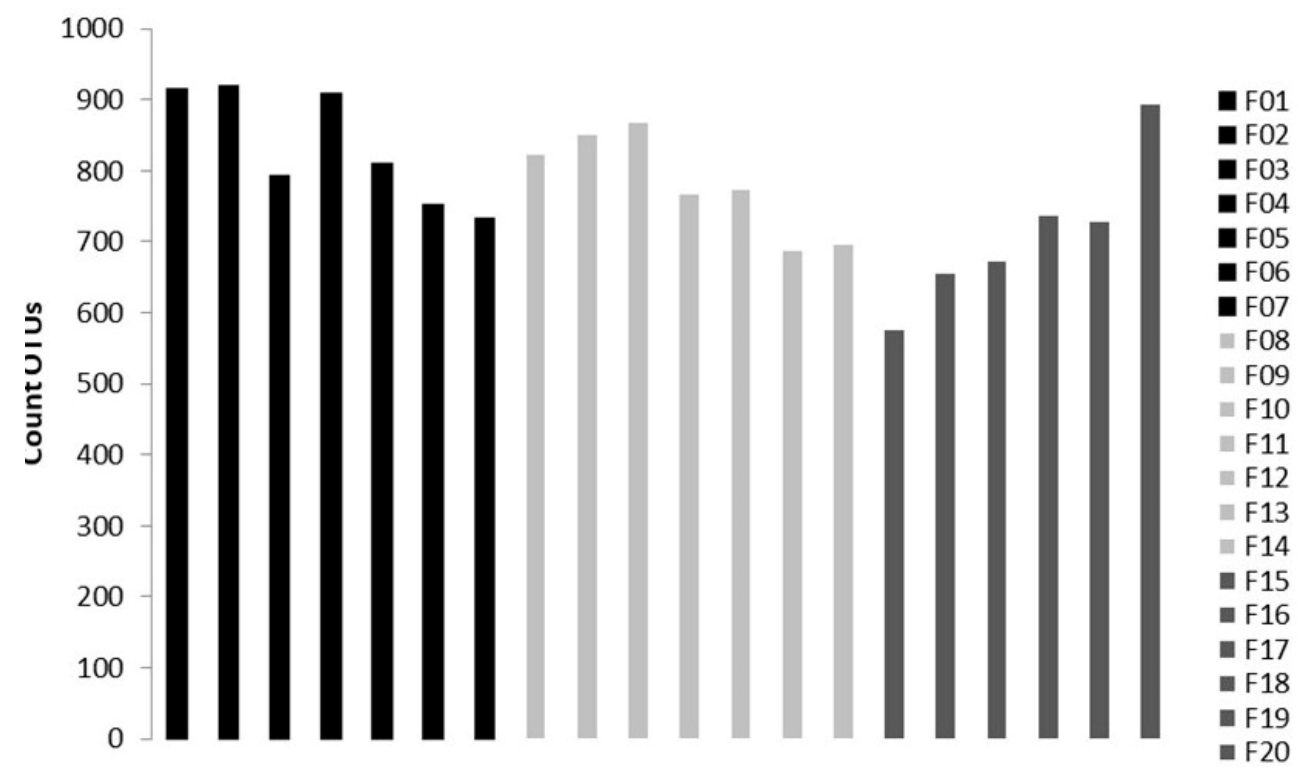

Figure 2. Number of OTUs present in each sample, with F1, F2, F3, F4, F5, F6, F7 belonging to altitudinal level L1, F8, F9, F10, F11, F12, F13, F14 beloning to L2, and F15, F16, F17, F18, F19, F20 belonging to L3.

Metagenomic data were taxonomically organized in this work following the highlevel classification of the Fungi reported by Tedersoo et al. [40]. The analysis revealed the presence of seven identified phyla in the soil samples: Ascomycota and Basidiomycota (subkingdom of Dikarya), Mortierellomycota, Mucoromycota and Glomeromycota (subkingdom Mucoromyceta), and Chytridiomycota and Monoblepharomycota (subkingdom Chytridiomyceta). The most abundant phylum was Ascomycota, with a relative abundance of $32-36 \%$, followed by Mortierellomycota (25-28\%), Basidiomycota (9-11\%), and Mucoromycota (3-7\%). The less abundant phyla were, as expected, Glomeromycota, $(0.1 \%)$ Chytridiomycota $(0.02 \%)$, and Monoblepharomycota $(0.0005 \%)$. The identified phyla were equally distributed in each sampling site, except Glomeromycota, which was more abundant in Site L3, the highest in altitude. The share of fungal OTUs assigned to "Unidentified" was quite abundant in each site, reaching $17-35 \%$ of the total. In total, 408 taxa identified at the species level were found. All recorded species with their relative abundances in each sampling site are listed in Supplementary Table S2.

\subsubsection{Subkingdom Dikarya Ascomycota}

Within the phylum Ascomycota, the analysis revealed the recording of 11 classes (Figure 3). The most abundant classes were Sordariomycetes (8-17\% of the total fungi), mainly represented by the orders Hypocreales and Chaetospheriales; Leotiomycetes (3-9\% of the total fungi), mainly represented by the order Helotiales; Eurotiomycetes (2-8\% of the total 
fungi), mainly represented by Eurotiales and Chaetotyriales; and Dothideomycetes ( $2-5 \%$ of the total fungi) mainly represented by Pleosporales (Figure 4).

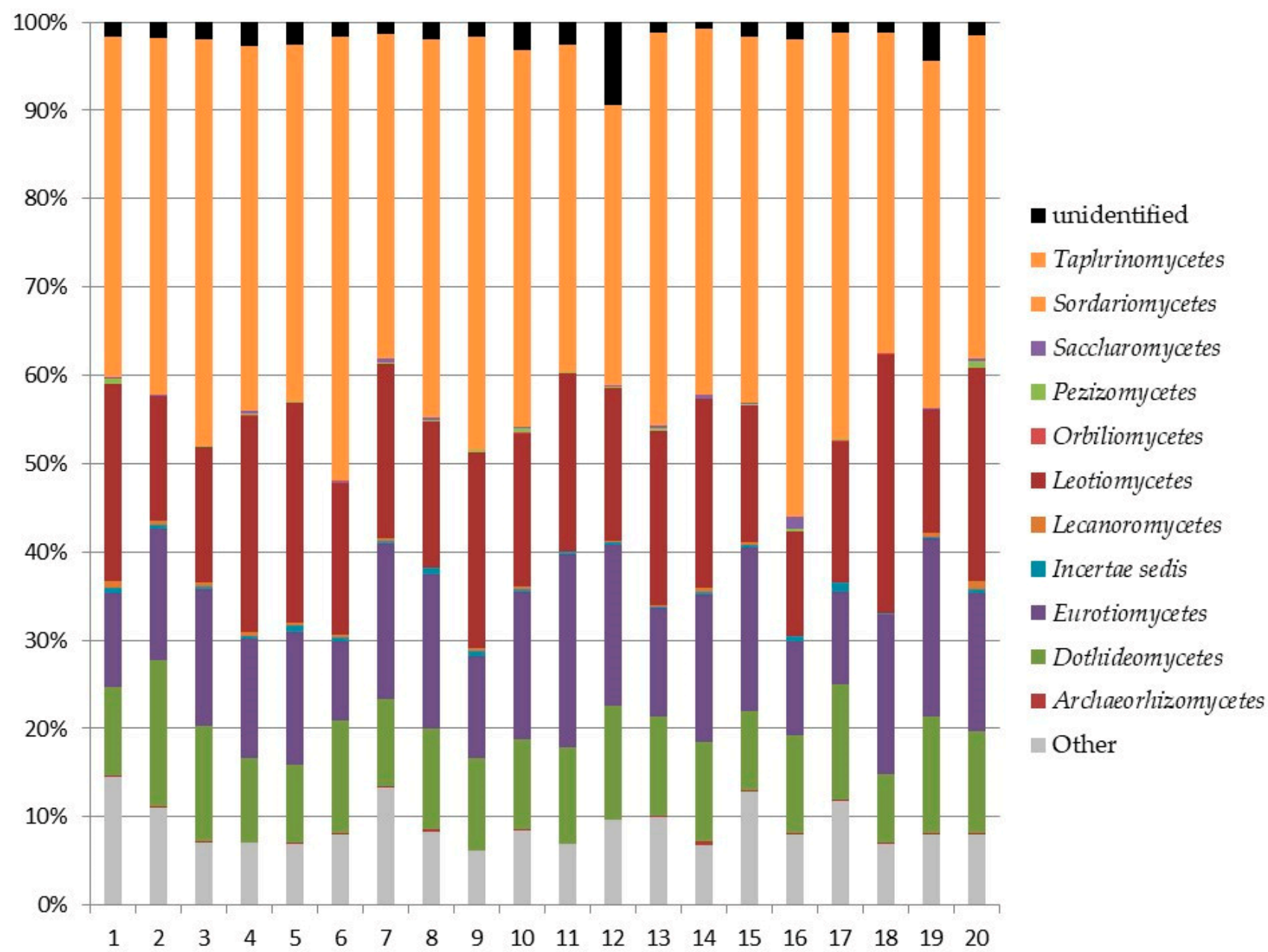

Figure 3. Relative abundance of Ascomycota classes in the soil samples.

In Ascomycota, 263 identified genera were recorded; 58 genera reached at least $0.1 \%$ of the total fungi and were present in at least one of the samples with this value. Among them, the most abundant genera were: Fusarium (6-12\%), Penicillium (0.5-6\%), Oidiodendron $(0.1-2 \%)$, Bipolaris $(1-2 \%)$, and Ilyonectria $(0.4-1 \%)$. The other genera were recorded at less than $0.01 \%$.

The ascomycetous taxa identified at the species level were 235 (Supplementary Table S2). Most of them belonged to Penicillium (nine species); Trichoderma (six), Oidiodendron (five), Cladonia, Cyphellophora, Exophiala, Peltigera, and Phialophora (all with four species each), and Acremonium, Aspergillus, Chalara, Chlonostachys, Hirsutella, and Metarhizium (three species each).

Top Ten Most Abundant Species of Ascomycota

Among the identified taxa, Fusarium oxysporum s. lat. was, undoubtedly, the most abundant species, reaching $7-10 \%$ of the total fungal assemblage. Pleotrichocladium opacum was well represented (3\%), together with Penicillium spinulosum and Curvularia lunata $(2 \%)$. Other abundant identified species were Trichoderma asperellum and Ilyonectria panacis (1\%), Tetracladium apiense and Chaetosphaeria vermicularioides (up to $0.5 \%$ ), Leptobacillium leptobactrum (up to $0.4 \%$ ), and Penicillium donkii (up to $0.3 \%$ ). 


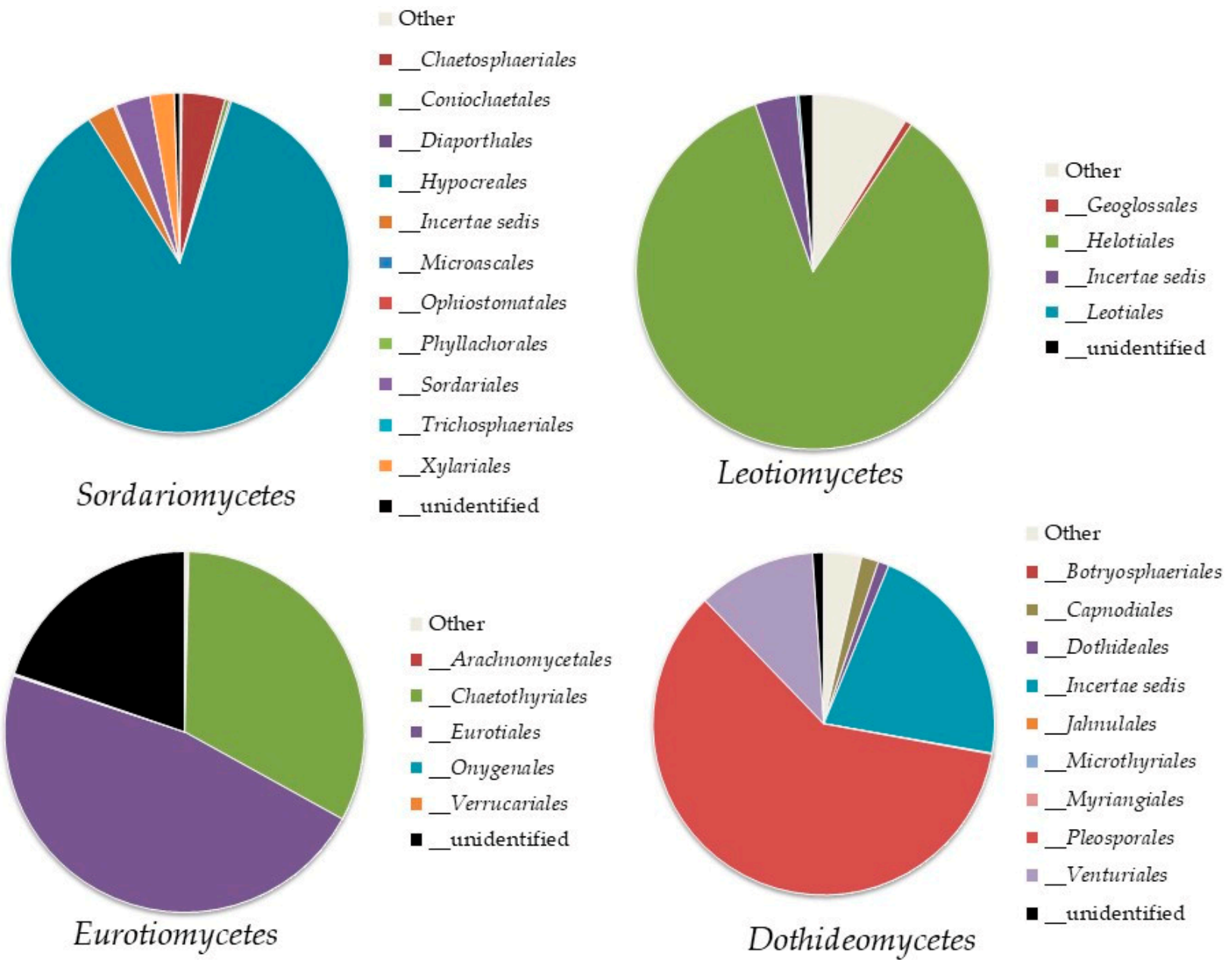

Figure 4. Order abundance in the most highly represented classes of Ascomycota: Sordariomycetes, Leotiomycetes, Eurotiomycetes, and Dothideomycetes.

\section{Basidiomycota}

Basidiomycota was represented by eight classes (Figure 5); the most abundant ones were Tremellomycetes, represented by the order Trichosporonales, and Agaricomycetes (both, up to $11 \%$ of the total fungi), mainly represented by the orders Agaricales and Thelephorales (Figure 6).

The recorded genera of Basidiomycota were 118. Only 29 of these genera reached at least $0.1 \%$ of abundance of the total fungi. Among them, the most abundant ones were: Cuphophyllus, Saitozyma, and Trichosporon (up to $7 \%$ of the total fungi), Tomentella (up to $6 \%$ ), and Hygrocybe (up to $2 \%$ ).

The basidiomycetous taxa identified at the species level were 127 (Supplementary Table S2). Most of the identified species belonged to Entoloma (11 species), and Lepiota (5 species).

Top Ten Abundant Species of Basidiomycota

The following species were the most abundant: Saitozyma podzolica (3-4\%), Apiotrichum wieringae (1-2.5\%), and Tomentella testaceogilva (1\%). Apiotrichum dulcitum, Clitocybe nebularis, Fomes fomentarius, Porpolomopsis calyptriformis, Sarcodon atroviridis, and Serendipita vermifera were represented by less than $0.2 \%$. 


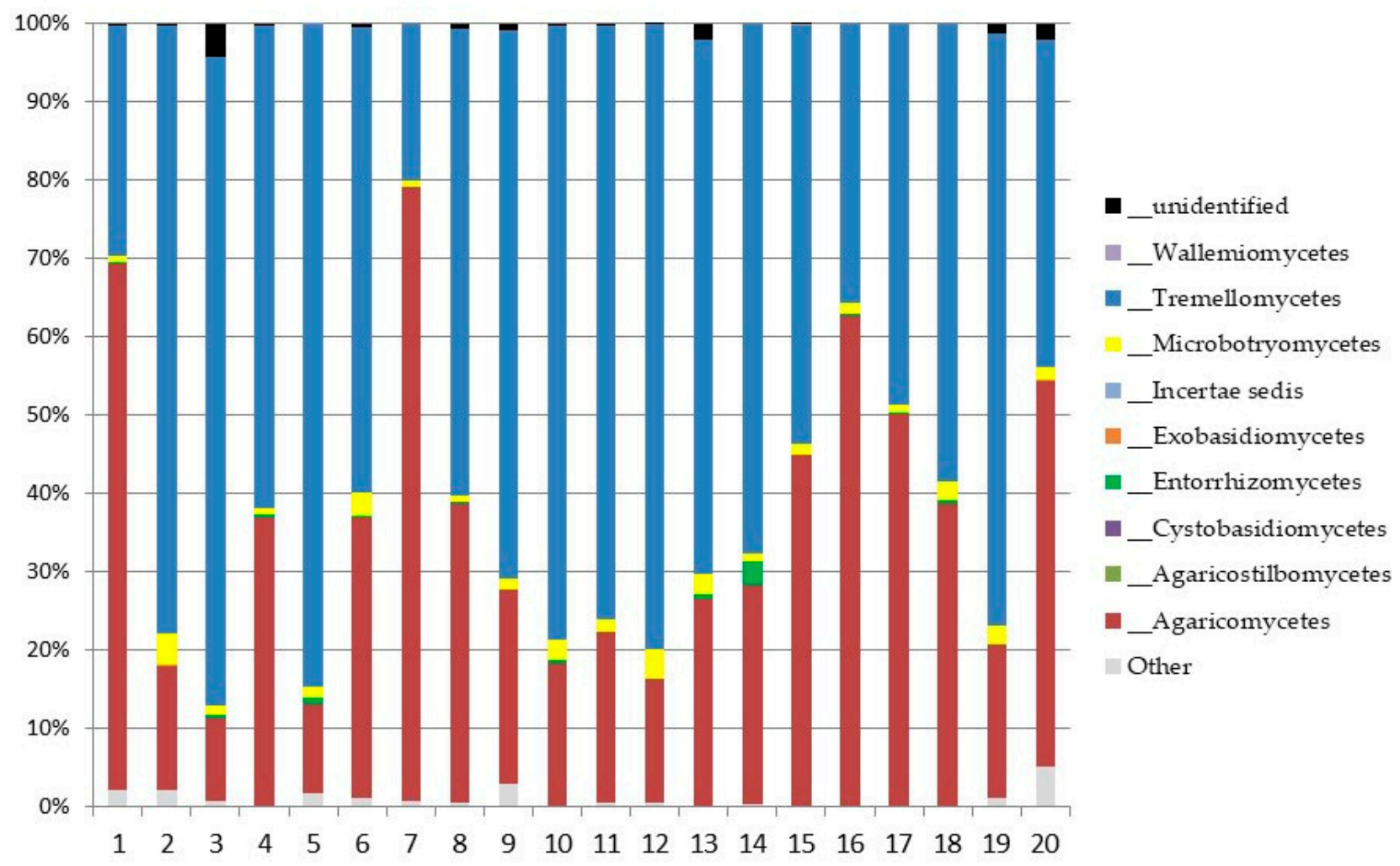

Figure 5. Relative abundance of classes of Basidiomycota in the soil samples.

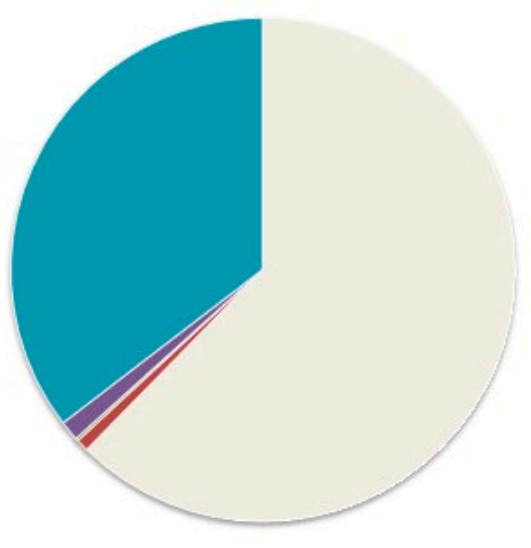

Tremellomycetes

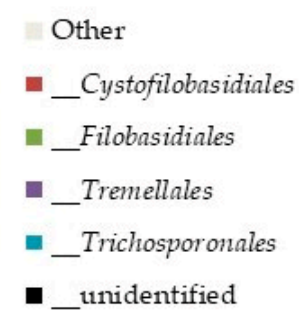

- _unidentified

Figure 6. Abundance of orders in the most represented classes of Basidiomycota: Tremellomycetes and Agaricomycetes.

\subsubsection{The Subkingdom Mucoromyceta Mortierellomycota}

Mortierellomycota was the second highest represented phylum. In the class Mortierellomycetes, the analysis revealed the presence of 5 genera and 12 species (Supplementary Table S2). The most dominant species were Podia verticillata (50\%), Podia horticola (21\%), Mortierella alpina, and Linnemannia gamsii (12\% each) (Figure 7). 


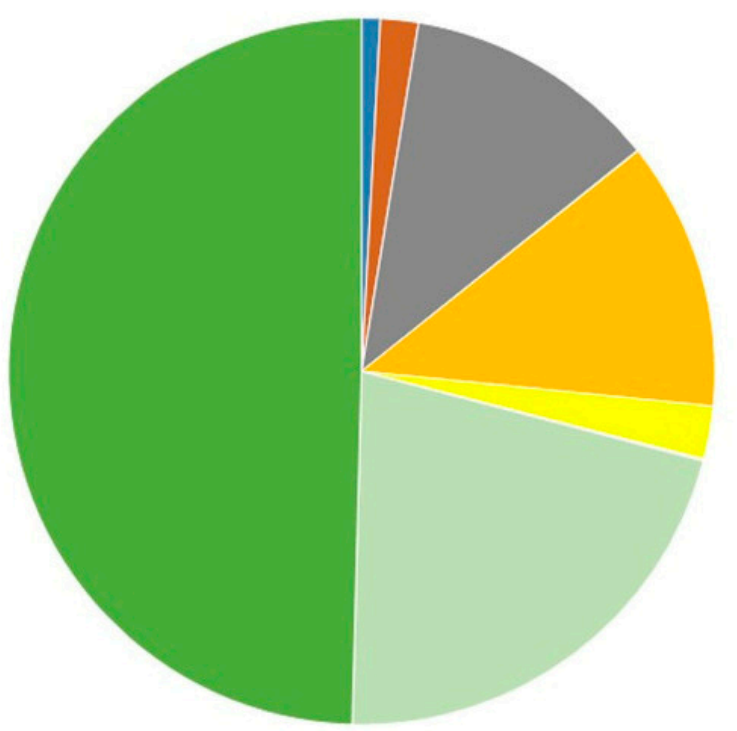

Figure 7. Relative abundance of species in Mortierellomycetes (Mortierellomycota), following the most recent taxonomic classification at the species level [41].

\section{Mucoromycota}

The three classes of Mucoromycota were all represented in the soil samples with a total of 19 species (Supplementary Table S2). Mucoromycetes (14 species) were dominated by Mucor moelleri (58\%), Mucor hiemalis, Sepmannia pineti (both 11\%), and Mucor abundans (10\%) (Figure 8). Umbelopsidiomycetes (four species) was completely dominated by Umbelopsis vinacea (97\%, Figure 8). Endogonomycetes was present with only one identified species, Jimgerdemannia lactiflua.
Relative abundance of Mucoromycetes species

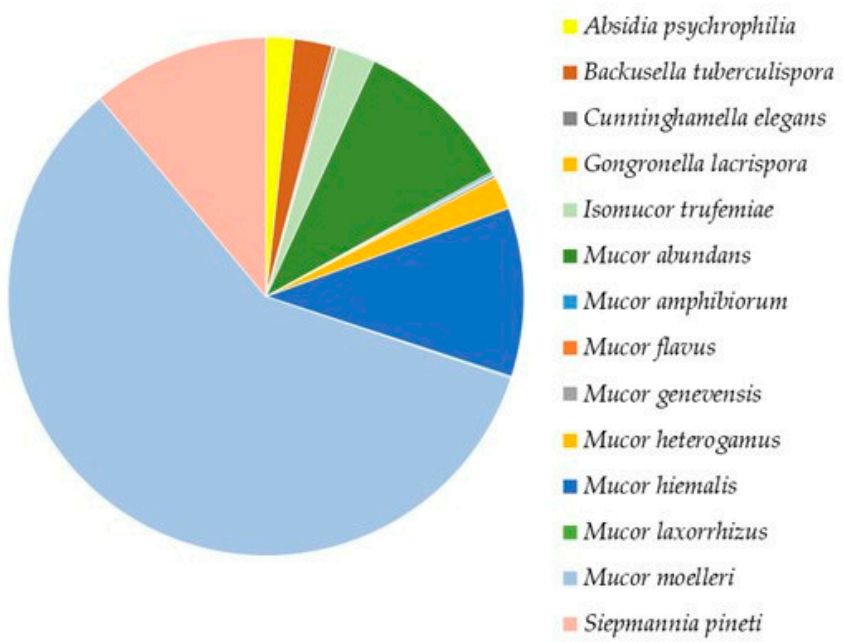

Relative abundance of Umbelopsidiomycetes species

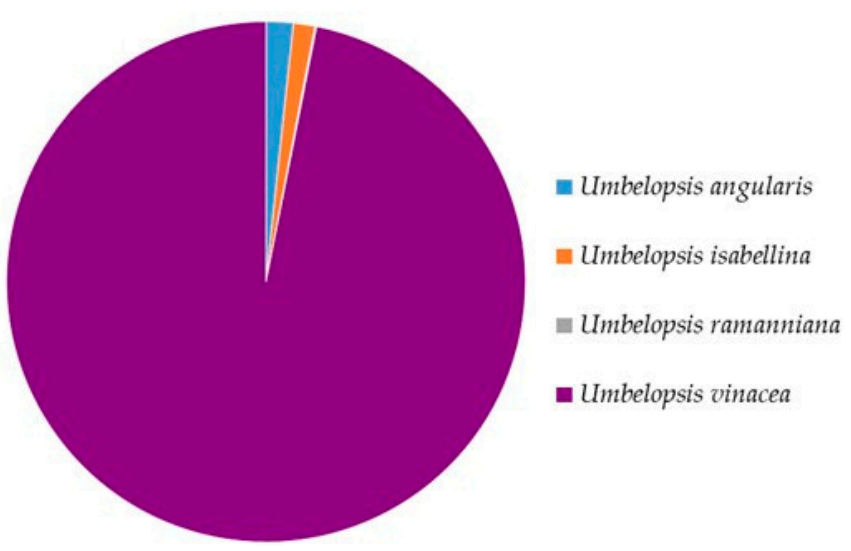

Figure 8. Relative abundance of species of Mucoromycota in the classes Mucoromycetes and Umbelopsidiomycetes.

Glomeromycota

The taxa belonging to this phylum were poorly identified at the species level. The detected species were seven (Supplementary Table S2), belonging to six genera: Claroideoglomus claroideum (2\%) followed by Acaulospora alpina, A. lacunosa, Racocetra castanea, R. fulgida, Archaeospora trappei, and Dentiscutata heterogama. 
The Top Mucoromyceta

Of the total fungi, Podila verticillata was strongly represented (12-14\%), followed by P. horticola (5-6\%), Mortierella alpina (2-6\%), Linnemannia gamsii (3\%), Umbelopsis vinacea (2.5-3\%), Mortierella biramosa (0.5-1\%), and Mucor moelleri (0.1-1\%).

\subsubsection{The Subkingdom Chytridiomyceta}

In Chytridiomyceta, the identified species were very rare (four, listed in Supplementary Table S2). The most abundant was Rhizophlyctis rosea (13\%), belonging to Chytridiomycota, followed by Spizellomyces plurigibbosus (6\%), Olpidium brassicae (1\%), and Gallinipes pseudodichotomus (1\%). In Monoblepharomycota, the only identified species was Monoblepharella mexicana (3\%).

\subsection{Soil Mycobiota Diversity in the Sampling Sites}

The alpha diversity found in the fungal communities of the three locations (L1, L2, L3) was similar regarding the Shannon and Simpson Indices, while the Chao 1 Index, which focuses especially on the abundance of rare species, found a significant difference between locations L1 and L3 (324 \pm 26 and $275 \pm 29$, respectively, $p<0.05$ ANOVA, followed by Tukey's pairwise test, Figure 9).
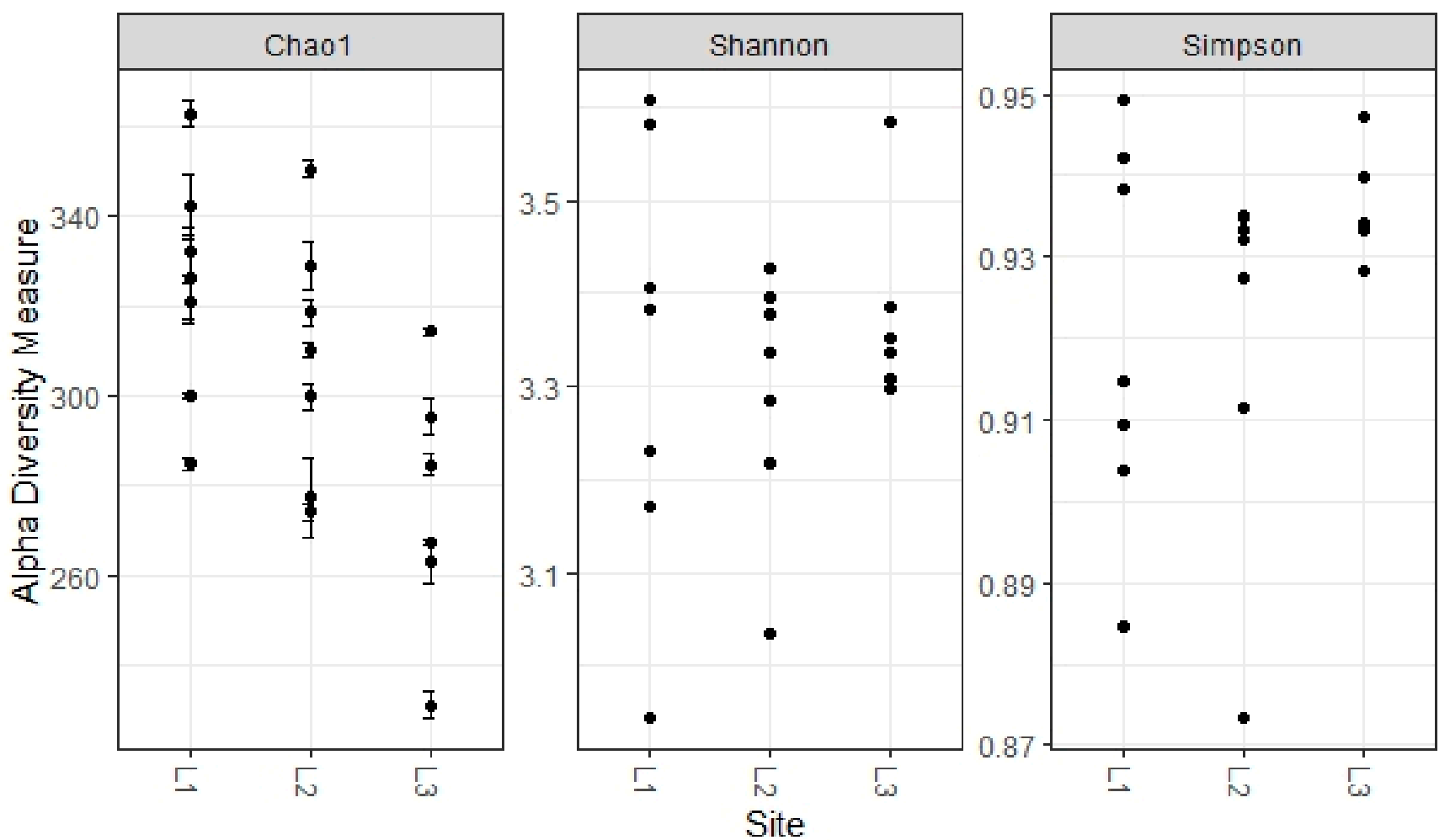

Figure 9. Estimated alpha diversity for different sampling sites.

The analysis of beta diversity present in the samples did not show any significant difference in the structure of soil fungal communities in the three sampling locations (PERMANOVA, $p>0.05$; Figure 10).

Venn's analysis showed that $43 \%$ of all OTUs was shared between the three sampling sites. At Locations L1 and L2, the number of unique OTUs was similar (129 and 133, respectively), while L3 had a lower number of unique OTUs (97, corresponding to 10\%) (Figure 11). 


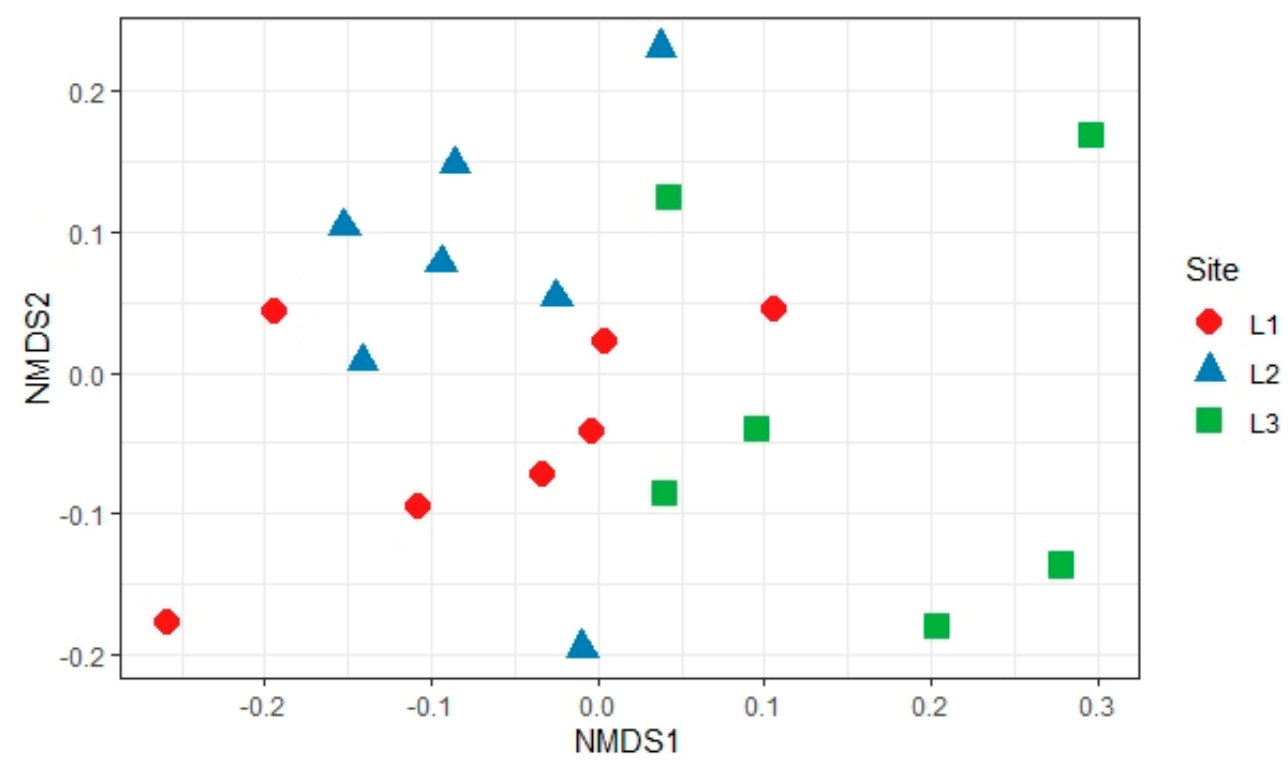

Figure 10. Non-Metric Multidimensional Scaling (NMDS) based on Bray-Curtis distances of soil fungal communities in the different sample locations (L1, L2, and L3) in the Aguarongo forest.

L1

L2

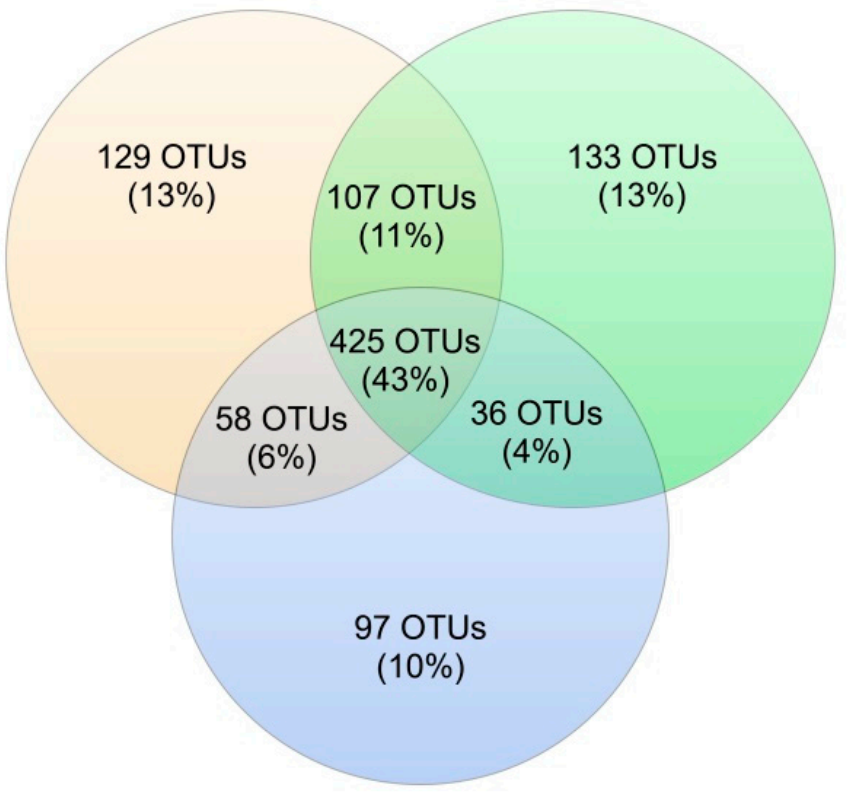

L3

Figure 11. Venn diagram showing OTUs shared among the 3 sampling sites (L1, L2, and L3).

\section{Discussion}

The Aguarongo forest reserve is one of the most important biodiversity hotspots in Ecuador, and in recent years, it has been the subject of numerous research studies on flora, fauna, use of soils, and water balance [28,42].

As for all the tropics, Ecuador has huge biodiversity that has yet to be revealed, especially in natural reserves such as the Aguarongo forest. This is true above all for Fungi, a Kingdom often neglected despite its key role in the functionality of terrestrial ecosystems.

Regarding the use of next-generation sequencing in research of soil fungal communities, there are few studies in the tropics; however, a collection of metagenomic data is being implemented [43-46]. Most Ecuadorian studies on soil fungi describe the diversity of arbuscular mycorrhizal fungi (AMF) associated with crops in the Andean part of Loja and 
Quito [47,48]. There are also studies of the communities of AMF associated with plants growing in contaminated soils such as crude-oil-contaminated sites in the Amazon region of Ecuador [20]. Using modern molecular methods, it was possible to obtain a detailed account of soil fungal biodiversity of the Aguarongo forest and give the first list of soil fungi of this important reserve of biodiversity in Ecuador.

In this work, 408 fungal OTUs were identified at the species level. Together with Ascomycota, the most abundant phylum in our study was Mortierellomycota. Its high abundance was expected, as this result has been recorded in other studies on the mycobiota of soil in high altitude environments $[44,46]$ or from extreme environments such as the Alps [49] or Antarctica [50-52]. Surprisingly, in the Aguarongo forest, the abundance of Mortierellomycota is similar to that of Ascomycota. All the OTUs referring to Mucoromyceta in this study were updated following the recent paper of Vandepol et al. [41], in which the phylogeny of Mortierellaceae was resolved through a synthesis of multigene phylogenetics and phylogenomics. The present work significantly improved the global geography and environmental records of Mortierellaceae and contributed to the knowledge on the ecology of these species, especially in an under-sampled region such as Ecuador. These data contribute to understanding the ecological function of Mortierellaceae, which remains mostly unknown. Species of Mortierellaceae are often isolated from soils, decaying leaves, and insects [53], due to their saprotrophic nature [54].

Regarding alpha diversity, it was similar among all sampling sites; the values reported here are similar to those found for other regions of the world with altitudes above 2000 m.a.s.l. [44].

In the whole soil mycobiota of Aguarongo, the most frequent species is a Mortierellaceae species, Podila verticillate, representing $12-14 \%$ of the total of identified OTUs. This species (reported with its basionym Mortierella verticillata) was first recorded in South America from mountainous environments (1950 m.a.s.1.) in Brazil [55]. Our findings expand the distribution of $P$. verticillata both in latitude and altitude. This is true for all of the species of Mortierellaceae, which were abundantly found in Aguarongo forest soil up to 3221 m.a.s.l.

Within the identified species of Ascomycetes in Aguarongo, important facultative plant pathogenic fungi were abundantly recorded, for example from the Fusarium oxysporum complex, a well-known group of taxa due to their many pathogenic forms and high frequency of isolation in soil [56], and Curvularia lunata, an important pathogen of maize [57]. In addition to the plant pathogens many saprotrophic fungi were recorded, such as Pleotrichocladium opacum and Penicillium spinulosum, a dominant taxon in the Aguarongo forest.

Beneficial fungi were not lacking, such as Trichoderma asperellum, an important biocontrol agent, applied in agriculture for controlling plant fungal pathogens and plant-growth promoters [58,59], as well as Arthrobotrys musiformis Pochonia bulbillosa, and P. suchlasporia, well-known nematophagous fungi [60,61]. Particularly important in the Aguarongo forest is the presence of the genus Metarhizium, a genus that shows wide biodiversity in this area, with species having high potential as biocontrol agents against insects, specifically $M$. anisopliae, M. flavoviride, and M. lepidiotae, [62]. Although their presence is occasional, many other species with importance because of their ecological role as entomopathogens or nematopathogens, and potential application for sustainable agriculture [63] are found in the Aguarongo forest. This includes Beauveria brongniartii, B. bassiana, Dactylella mammillata, Hirsutella minnesotensis, H. rhossiliensis, H. vermicola, Paecilomyces farinosus, and P. marquandii.

Basidiomycetes were dominated by Saitozyma podzolica, a common yeast and strong decomposer of dead plant biomass isolated from soils worldwide [64]. Apiotrichum wieringae was also widely present in the soil of Aguarongo, a nonpathogenic member of the Tricosporonaceae family, able to degrade uric acid and aromatic compounds [65]. Tomentella testaceogilva, abundant in Aguarongo, is reported as a terricolous or lignicolous fungus associated with Alnus, but also with moss [66]. Although rarely recorded in the Aguarongo forest, a famous member of Basidiomycetes must be highlighted, namely Fomes fomentarius, an important plant pathogenic fungus rich in pharmacological compounds [67]. 
Fungi in soils of Aguarongo include members of the phylum Glomeromycota, which remain mainly unidentified. Some identified species are important arbuscular mycorrhizal fungi; the most abundant one was Claroideoglomus claroideum, considered a good plant promoter and heavy metal decontaminant [68]. In the Aguarongo forest, Chytridiomycota were dominated by Rhizophlyctis rosea, a highly effective plant biomass degrader and zoosporic fungus, commonly observed near the soil surface. This species has light-sensitive proteins that allow this fungus to remain in the euphotic zone [69]. Within Monoblepharomycota, only one species was recorded: Monoblepharella mexicana. The southernmost record of this species was reported by Steciow and Arambarri [70], while the present finding can be considered the record of this species at the highest elevation.

The analysis reported in this work is based on a large number of soil samples (100), thus giving a good representation of the fungal biodiversity of Aguarongo forest soil. The collection of samples along an altitudinal gradient did not reveal significant differences among the structure of the soil fungal communities in the three sampling locations (L1, L2, L3). Only Location L3 has a lower abundance of rare taxa with respect to L1, consistent with the Venn diagram.

The analysis of the records, reported in Supplementary Table S2, shows the Aguarongo forest soils as a natural area rich in fungal biodiversity, with the main phyla represented by a large number of taxa, known to be beneficial fungi. In addition, the Aguarongo forest is shown to be a rich source of species having strong application potential in agriculture and in the chemical and food industry. This area hides a huge number of unknown species that could be assessed, and its protection is of the utmost importance.

Supplementary Materials: The following are available online at https: / www.mdpi.com/article / 10.3390/biology10121289/s1, Table S1: Description of the pooling of the samples; Table S2: Species recorded in Aguarongo forest soil at the three altitudinal level (L1, L2, L3).

Author Contributions: E.F.D. and A.T.V. performed the experiments; S.A.C. and A.T.V. contributed with reagents/materials/analysis tools; S.A.C. and L.N. analyzed the data; E.F.D., L.N. and S.T., wrote the paper. All authors have read and agreed to the published version of the manuscript.

Funding: This research received no external funding.

Institutional Review Board Statement: Not applicable.

Informed Consent Statement: Not applicable.

Data Availability Statement: High-performance sequencing datasets were deposited in the NCBI Biosamples data with access numbers SAMN11854455, SAMN11854456 197, and SAMN11854457 for Location 1, Location 2, and Location 3 ITS DNA metabarcoding libraries, respectively.

Acknowledgments: We would like to thank Javier Herran Rector of the Salesian Polytechnic University of Ecuador for the support and financing provided. We would also like to thank ID Metagenomics for their useful help in the analysis of metagenomic data.

Conflicts of Interest: The authors declare no conflict of interest.

\section{References}

1. Tedersoo, L.; Bahram, M.; Põlme, S.; Koljag, U.; Yorou, N.S.; Wijesundera, R.; Virreal Ruiz, L.; Vasco-Palacios, A.M.; Thu, P.Q.; Suija, A.; et al. Global diversity and geography of soil fungi. Science 2014, 346, 1078. [CrossRef]

2. Mueller, G.M.; Schmit, J.P.; Leacock, P.R.; Buyck, B.; Cifuentes, J.; Dejardin, D.E.; Halling, R.E.; Hjortstam, K.; Iturriaga, T.; Larsson, K.H.; et al. Global diversity and distribution of macrofungi. Biodivers. Conserv. 2007, 16, 37-48. [CrossRef]

3. Tedersoo, L.; Jairus, T.; Horton, B.M.; Abarenkov, K.; Suvi, T.; Saar, I.; Kõljalg, U. Strong host preference of ectomycorrhizal fungi in a Tasmanian wet sclerophyll forest as revealed by DNA barcoding and taxon-specific primers. New Phytol. 2008, 180, 479-490. [CrossRef]

4. Thakur, M.P.; Geisen, S. Trophic Regulations of the Soil Microbiome. Trends Microbiol. 2019, 27, 771-780. [CrossRef]

5. Vandenkoornhuyse, P.; Baldauf, S.L.; Leyval, C.; Straczek, J.; Young, J.P.W. Extensive fungal diversity in plant roots. Science 2002, 295, 2051. [CrossRef] 
6. Banchi, E.; Ametrano, C.G.; Tordoni, E.; Stankovi, D.; Ongaro, S.; Tetiach, M.; Pallavicini, A.; Muggia, L.; Verardo, P.; Tassan, F.; et al. Environmental DNA assessment of airborne plant and fungal seasonal diversity. Sci. Total Environ. 2020, 738, 140249. [CrossRef] [PubMed]

7. Coleine, C.; Selbmann, L.; Pombubpa, N.; Stajich, J.E. Amplicon sequencing of rock inhabiting microbial communities from Joshua Tree National Park, USA. Microbiol. Resour. Announc. 2021, 10, e00494-21. [CrossRef]

8. Seifert, K.A. Progress towards DNA barcoding of fungi. Mol. Ecol. Resour. 2009, 9, 83-89. [CrossRef]

9. Peay, K.; Kennedy, P.; Talbot, J. Dimensions of biodiversity in the Earth mycobiome. Nat. Rev. Microbiol. 2016, $14,434-447$. [CrossRef] [PubMed]

10. Thomsen, P.F.; Willerslev, E. Environmental DNA-An emerging tool in conservation for monitoring past and present biodiversity. Biol. Conserv. 2015, 83, 4-18. [CrossRef]

11. Toapanta-Alban, C.E.; Ordoñez, M.E.; Barnes, C.W.; Blanchette, R.A. Taxonomy of the major rhizomorphic species of the "Melanopus group" within Polyporaceae in Yasunı' National Park, Ecuador. PLoS ONE 2021, 16, e0254567. [CrossRef] [PubMed]

12. Liu, J.; Haelewaters, D.; Pfliegler, W.P.; Page, R.A.; Dick, C.W.; Aime, M.C. A new species of Gloeandromyces from Ecuador and Panama revealed by morphology and phylogenetic reconstruction, with a discussion of secondary barcodes in Laboulbeniomycetes taxonomy. Mycologia 2020, 112, 1192-1202. [CrossRef] [PubMed]

13. Crous, P.W.; Wingfield, M.J.; Chooi, Y.H.; Gilchrist, C.L.M.; Lacey, E.; Pitt, J.I.; Roets, F.; Swart, W.J.; Cano-Lira, J.F.; ValenzuelaLopez, N.; et al. Fungal Planet description sheets: 1042-1111. Persoonia 2020, 44, 301-459. [CrossRef]

14. Galarza, L.; Akagi, Y.; Takao, K.; Kim, C.S.; Maekawa, N.; Itai, A.; Peralta, E.; Santos, E.; Kodama, M. Characterization of Trichoderma species isolated in Ecuador and their antagonistic activities against phytopathogenic fungi from Ecuador and Japan. J. Gen. Plant. Pathol. 2015, 81, 201-210. [CrossRef]

15. Baroni, T.J.; Halling, R.E. New species of Rhodocybe from South America with a key to species. Mycologia 1992, 84, 411-421. [CrossRef]

16. Goh, T.K.; Hyde, K.D. A new species of Palmicola from Ecuador. Mycol. Res. 1996, 100, 714-716. [CrossRef]

17. Berndt, R. New Puccinia species on Baccharis from Ecuador and Costa Rica. Mycol. Res. 1998, 102, 1108-1112. [CrossRef]

18. Garcés, F.F.; Fiallos, F.F.; Silva, E.; Martinez, F.; Aime, M.C.; Comstock, J.C.; Glynn, N.C.; Castlebury, L.A. First Report of Orange Rust of Sugarcane Caused by Puccinia kuehnii in Ecuador. Plant. Dis. 2014, 98, 842. [CrossRef] [PubMed]

19. Dueñas, J.F.; Camenzind, T.; Roy, J.; Hempel, S.; Homeier, J.; Suárez, J.P.; Rillig, M.C. Moderate phosphorus additions consistently affect community composition of arbuscular mycorrhizal fungi in tropical montane forests in southern Ecuador. New Phytol. 2020, 227, 1505-1518. [CrossRef]

20. Garcés-Ruiz, M.; Senés-Guerrero, C.; Declerck, S.; Cranenbrouck, S. Community composition of arbuscular mycorrhizal fungi associated with native plants growing in a petroleum-polluted soil of the Amazon region of Ecuador. Microbiologyopen 2019, 8, e00703. [CrossRef]

21. Jaswal, R.; Pathak, A.; Edwards, B., III; Lewis, R., III; Seaman, J.C.; Stothard, P.; Krivushin, K.; Blom, J.; Rupp, O.; Chauhan, A. Metagenomics-Guided Survey, Isolation, and Characterization of Uranium Resistant Microbiota from the Savannah River Site, USA. Genes 2019, 10, 325. [CrossRef] [PubMed]

22. Rundell, S.M.; Spakowicz, D.J.; Narváez-Trujillo, A.; Strobel, S.A. The Biological Diversity and Production of Volatile Organic Compounds by Stem-Inhabiting Endophytic Fungi of Ecuador. J. Fungi 2015, 1, 384-396. [CrossRef] [PubMed]

23. Novotná, A.; Ângel Benítez, A.; Herrera, P.; Cruz, D.; Filipczyková, E.; Suárez, J.P. High diversity of root-associated fungi isolated from three epiphytic orchids in southern Ecuador. Mycoscience 2018, 59, 24-32. [CrossRef]

24. Tedersoo, L.; Sadam, A.; Zambrano, M.; Valencia, R.; Bahram, M. Low diversity and high host preference of ectomycorrhizal fungi in Western Amazonia, a neotropical biodiversity hotspot. ISME J. 2010, 4, 465-471. [CrossRef] [PubMed]

25. Haug, I.; Setaro, S.; Suárez, J.P. Global AM fungi are dominating mycorrhizal communities in a tropical premontane dry forest in Laipuna, South Ecuador. Mycol. Progress 2021, 20, 837-845. [CrossRef]

26. Setaro, S.; Suárez, J.P. Species composition of arbuscular mycorrhizal communities changes with elevation in the Andes of South Ecuador. PLoS ONE 2019, 14, e0221091.

27. Minga, N.O. Experience to Protection and Management of Native Andean Forests in the South of Ecuador. Lyonia 2003, 4, 157-164.

28. Dunque-Sarango, P.; Cajamarca-Rivadeneira, R.; Wemple, B.C.; Delgado- Fernández, M.E. Estimation of the water balance of for a small tropical andean catchment. LA GRANJA Rev. Cienc. Vida 2019, 29, 56-69.

29. Uroz, S.; Ioannidis, P.; Lengelle, J.; Cébron, A.; Morin, E.; Buée, M.; Martin, F. Functional assays and metagenomic analyses reveals differences between the microbial communities inhabiting the soil horizons of a Norway spruce plantation. PLoS ONE 2013, 8, e55929. [CrossRef] [PubMed]

30. Bloem, J.; Hopkins, D.W.; Benedetti, A. Microbiological Methods for Assessing Soil Quality; CABI Publishing: London, UK, 2006; p. 307.

31. Euherabide, M.; Saínz Rozas, H.; Barbieri, P.; Echeverría, H.E. Comparación de métodos para determinar carbono orgánico en suelo. Cienc. Suelo 2014, 32, 13-19.

32. White, T.J.; Bruns, T.; Lee, S.; Taylor, J. Amplification and direct sequencing of fungal ribosomial RNA genes for phylogenetics. In PCR Protocols a Guide to Methods and Applications; Innis, M.A., Gelfand, D.H., Sninsky, J.J., White, T.J., Eds.; Academic Press: San Diego, CA, USA, 1990; pp. 315-322. 
33. Caporaso, J.; Kuczynski, J.; Stombaugh, J.; Bittinger, K.; Bushman, F.D.; Costello, E.K.; Fierer, N.; Pena, A.G.; Goodrich, J.K.; Gordon, J.I.; et al. QIIME allows analysis of high-throughput community sequencing data. Nat. Methods 2010, 7, 335-336. [CrossRef] [PubMed]

34. Callahan, B.J.; McMurdie, P.J.; Rosen, M.J.; Han, A.W.; Johnson, A.J.A.; Holmes, S.P. DADA2: High-resolution sample inference from Illumina amplicon data. Nat. Methods 2016, 13, 581-583. [CrossRef]

35. Rognes, T.; Flouri, T.; Nichols, B.; Quince, C.; Mahé, F. VSEARCH: A versatile open source tool for metagenomics. PeerJ 2016, 4, e2584. [CrossRef]

36. Kõljalg, U.; Nillson, R.H.; Abarenkov, K.; Tedersoo, L.; Taylor, A.F.S.; Bahram, M.M.; Bates, S.T.; Bruns, T.D.; Bengtsson-Palme, J.; Callaghan, T.M.; et al. Towards a unified paradigm for sequence-based identification of fungi. Mol. Ecol. 2013, 22, $5271-5277$. [CrossRef]

37. R Core Team. R: A Language and Environment for Statistical Computing. R Foundation for Statistical Computing. Available online: https: / /www.R-project.org (accessed on 7 February 2018).

38. McMurdie, P.J.; Holmes, S. Phyloseq: An R Package for Reproducible interactive Analysis and Graphics of Microbiome Census Data. PLoS ONE 2013, 8, e61217. [CrossRef]

39. Oksanen, J.; Blanchet, F.G.; Kindt, R.; Legendre, P.; Minchin, P.R.; O'Hara, R.B.; Simpson, G.L.; Solymos, P.; Stevens, M.H.H.; Wagner, H. Vegan: Community Ecology Package. R Package Version 2.0-10. 2013. Available online: http:/ /CRAN.R-project.org/ package $=$ vegan (accessed on 7 February 2018).

40. Tedersoo, L.; Sánchez-Ramírez, S.; Kõljalg, U.; Bahram, M.; Doring, M.; Schigel, D.; May, T.; Ryberg, M.; Abarenkov, K. High-level classification of the Fungi and a tool for evolutionary ecological analyses. Fungal Divers. 2018, 90, 135-159. [CrossRef]

41. Vandepol, N.; Liber, J.; Desirò, A.; Na, H.; Kennedy, M.; Barry, K.; Grigoriev, I.V.; Miller, A.N.; O’Donnell, K.; Stajich, J.E.; et al. Resolving the Mortierellaceae phylogeny through synthesis of multi-gene phylogenetics and phylogenomics. Fungal Divers. 2020, 104, 267-289. [CrossRef] [PubMed]

42. Fredi, F.; Parra, R.P.; Zumba, D.A. Bromeliads of the Aguarongo Protective Forest-Ecuador and Adaptation to Climate Change. J. Eng. Appl. Sci. 2017, 12, 1619-1622.

43. Vaz, A.B.M.; Fonseca, P.L.C.; Leite, L.R.; Badotti, F.; Salim, A.C.M.; Flavio, M.G.; Araujo, F.M.G.; Cuadros-Orellana, S.C.; Duarte, Â.A.; Rosa, C.A.; et al. Using next-generation sequencing (NGS) to uncover diversity of wood-decaying fungi in neotropical atlantic forests. Phytotaxa 2017, 295, 001-021. [CrossRef]

44. Landínez-Torres, A.Y.; Panelli, S.; Picco, A.M.; Comandatore, F.; Tosi, S.; Capelli, E. A meta-barcoding analysis of soil myco-biota of the upper Andean Colombian agro-environment. Sci. Rep. 2019, 9, 10085. [CrossRef]

45. Landínez-Torres, A.Y.; Abril, J.L.B.; Tosi, S.; Nicola, L. Soil Microfungi of the Colombian Natural Regions. Int. J. Environ. Res. Public Heal. 2020, 17, 8311. [CrossRef]

46. Nicola, L.; Landínez-Torres, A.Y.; Zambuto, F.; Capelli, E.; Tosi, S. The Mycobiota of High Altitude Pear Orchards Soil in Colombia. Biology 2021, 10, 1002. [CrossRef]

47. Senés-Guerrero, C.; Schüßler, A. A conserved arbuscular mycorrhizal fungal core- species community colonizes potato roots in the Andes. Fungal Divers. 2016, 77, 317-333. [CrossRef]

48. Loján, P.; Senés-Guerrero, C.; Suárez, J.P.; Kromann, P.; Schüßler, A.; Declerck, S. Potato field-inoculation in Ecuador with Rhizophagus irregularis: No impact on growth performance and associated arbuscular mycorrhizal fungal communities. Symbiosis 2017, 73, 45-56. [CrossRef]

49. Rodolfi, M.; Longa, C.M.O.; Pertot, I.; Tosi, S.; Savino, E.; Guglielminetti, M.; Altobelli, E.; Del Frate, G.; Picco, A.M. Fungal biodiversity in the periglacial soil of Dosde Glacier (Valtellina, Northern Italy). J. Basic Microbiol. 2016, 56, 263-274. [CrossRef]

50. Tosi, S.; Casado, B.; Gerdol, R.; Caretta, G. Fungi isolated from antarctic mosses. Polar Biol. 2002, 25, 262-268. [CrossRef]

51. Santos, J.A.D.; Meyer, E.; Sette, L.D. Fungal Community in Antarctic Soil Along the Retreating Collins Glacier (Fildes Peninsula, King George Island). Microorganisms 2020, 8, 1145. [CrossRef]

52. Canini, F.; Geml, J.; D'Acqui, L.P.; Selbmann, L.; Onofri, S.; Ventura, S.; Zucconi, L. Exchangeable cations and pH drive diversity and functionality of fungal communities in biological soil crusts from coastal sites of Victoria Land, Antarctica. Fungal Ecol. 2020, 45, 100923. [CrossRef]

53. Domsch, K.H.; Gams, W.; Anderson, T.H. Compendium of Soil Fungi; Academic Press: London, UK, 1980.

54. Tamayo-Vélez, Á.; Osorio, N.W. Soil Fertility Improvement by Litter Decomposition and Inoculation with the Fungus Mortierella sp. in Avocado Plantations of Colombia. Commun. Soil Sci. Plan. 2018, 49, 139-147. [CrossRef]

55. Gonçalves, C.M.; Oliveira, R.J.V.; Silva, R.M.F.; Souza, C.A.F.; Lima, D.X.; Silva, G.A. Mortierella verticillata Linnem (Mortierellomycota, Mortierellales) isolated from mountainous environments: A first report from South America. Check List 2020, 16, 907-910. [CrossRef]

56. Smith, S.N. An Overview of Ecological and Habitat Aspects in the Genus Fusarium with Special Emphasis on the Soil Borne Pathogenic Forms. Plant Pathol. Bull. 2007, 16, 97-120.

57. Chang, J.; Liu, S.; Shi, J.; Guo, N.; Zhang, H.; Chen, J. A new Curvularia lunata variety discovered in Huanghuaihai Region in China. J. Integr. Agr. 2020, 19, 551-560. [CrossRef]

58. Watanabe, S.; Kato, H.; Kumakura, K.; Ishibashi, E.; Nagayama, K. Properties and biological control activities of aerial and submerged spores in Trichoderma asperellum SKT-1. J. Pestic. Sci. 2006, 31, 375-379. [CrossRef] 
59. Chagas Junior, A.F.; Chagas, L.F.B.; Miller, L.D.O.; de Oliveira, J.C. Efficiency of Trichoderma asperellum UFT 201 as plant growth promoter in soybean. Afr. J. Agr. Res. 2019, 14, 263-271.

60. Nicola, L.; Tosi, S.; Savini, D. In vitro evaluation of nematophagous activity of fungal isolates. J. Basic Microbiol. 2014, 54, 1-5. [CrossRef] [PubMed]

61. Angeles-Hernández, S.; Torres-Hernández, G.; Alonso-Díaz, M.A.; von Son-de-Fernex, E.; Aguilar-Marcelino, L.; GonzálezGarduño, R.; Becerril-Pérez, C.M.; Alcántara-Carbajal, J.L.; Vargas-López, S.; Olmedo-Juárez, A.; et al. Effect of an Arthrobotrys musiformis (Fungi: Orbiliales) culture filtrate on the population of gastrointestinal parasitic nematode eggs in faeces of grazing lambs. Vet. Parasitol. Reg. Stud. Rep. 2021, 24, 100565. [CrossRef] [PubMed]

62. Iwanicki, N.S.; Pereira, A.A.; Botelho, A.B.R.Z.; Rezende, J.M.; Moral, R.D.; Zucchi, M.I.; Delalibera, I. Monitoring of the field application of Metarhizium anisopliae in Brazil revealed high molecular diversity of Metarhizium spp in insects, soil and sugarcane roots. Sci. Rep. 2019, 9, 4443. [CrossRef] [PubMed]

63. Amaresan, N.; Senthil Kumar, M.; Sankaranarayanan, M. Beneficial Microbes in Agro-Ecology: Bacteria and Fungi; Academic Press: Amsterdam, The Netherlands, 2020.

64. Mašínová, T.; Bahnmann, B.D.; Větrovský, T.; Tomšovský, M.; Merunková, K.; Baldrian, P. Drivers of yeast community composition in the litter and soil of a temperate forest. FEMS Microbiol. Ecol. 2017, 93, fiw223. [CrossRef]

65. Middelhoven, W.J. Trichosporon wieringae sp. nov., an anamorphic basidiomycetous yeast from soil, and assimilation of some phenolic compounds, polysaccharides and other non-conventional carbon sources by saprophytic Trichosporon species. Antonie van Leeuwenhoek 2004, 86, 329-337. [CrossRef]

66. Larsen, M.J.A. Contribution to the Taxonomy of the Genus Tomentella; New York Botanical Garden: New York, NY, USA, $1974 ;$ p. 145.

67. Gáper, J.; Gáperová, S.; Pristas, P.; Naplavova, K. Medicinal Value and Taxonomy of the Tinder Polypore, Fomes fomentarius (Agaricomycetes): A Review. Int. J. Med. Mushrooms 2016, 18, 851-859. [CrossRef]

68. Pérez, R.; Yasna Tapia, Y.; Antilén, M.; Manuel Casanova, M.; Vidal, C.; Santander, C.; Aponte, H.; Cornejo, P. Interactive effect of compost application and inoculation with the fungus Claroideoglomus claroideum in Oenothera picensis plants growing in mine tailings. Ecotoxicol. Environ. Safe 2021, 208, 111495. [CrossRef] [PubMed]

69. Gleason, F.H.; Pilgaard, B.; Henderson, L.; Lange, L. The key ecological role and biology of Rhizophlyctis rosea, a zoosporic, early lineage fungus in soil ecosystems. Curr. Trends Microbiol. 2019, 60, 67-80.

70. Steciow, M.M.; Arambarri, A.M. Southernmost occurrence of a tropical fungus: Monoblepharella mexicana (Gonapodyaceae, Chytridiomycota). Nova Hedwig. 2000, 70, 107-112. [CrossRef] 